\title{
Venereal Diseases, Prostitution and Lock Hospitals in 19th Century Awadh (Oudh)
}

\author{
*Dr Mumtaz Alam
}

\begin{abstract}
This study focusses on lock hospitals, venereal diseases, soldiers and prostitutes in Awadh. The colonial administration implemented a policy to protect soldiers from sexually transmitted diseases. In the nineteenth century across the globe British colonial administrations established legislation to stem the growing tide of venereal diseases and mid-nineteenth century the Contagious disease act was passed through which identified female prostitute on the principal source of contagion. This studies primarily based on the annual reports of lock hospitals and the data available in reports.
\end{abstract}

Keywords: lock hospital, Venereal Diseases, Contagious Disease act, Prostitution and Empire.

*Assistant Professor in History,Head of Deapartment-Social Science,Fiji National University, Fiji 
Webster's New World Dictionary defines the term 'Venereal Diseases' that diseases which are transmitted only or chiefly by sexual intercourse with an infected individual and there were two types of diseases i.e., Syphilis and Gonorrhea which is also known as Contagious diseases.

The Contagious Diseases Acts of 1864, 1866 and 1869 were introduced in England as legislation to control the spread of venereal diseases among enlisted men in garrison towns and ports. Under the Acts, a woman could be identified as a 'common prostitute' by a special plainclothes policeman and subjected to fortnightly internal examination. The prostitute if found suffering was to interned in a certified lock hospital for a period not exceeding nine months. ${ }^{1}$

The offices in military and medical establishments of colonial India agreed that preserving the health of European troops in India from the danger of 'mercenary love' must be one of their highest priorities. ${ }^{2}$

The discussion that follows focuses on the region of Awadh and the North-Western Provinces from the passing of the legislation in 1868 till the end of the century. It seeks to emphasize that venereal diseases were combated by immediate legislation and by the wider changes taking place in this region.

Though there is an abundance of work done on the region of Awadh and North Western Provinces on a number of themes none seeks to explain the venereal diseases and the institution of lock hospital with reference to its regional peculiarities or the change brought about by colonial rule whether subtle or apparent. Kenneth Ballhatchet's Race, Sex and Class under the Raj (1793-1905) focus on the Contagious Diseases Acts, British policy, the institution of the lock hospitals and their relationship with the Lal Bazaars, racial attitudes, and also raise a large number of interesting questions. Further, his emphasis is more or the Bengal, Bombay and Madras presidencies with occasional references to the region under study. ${ }^{3}$

Philippa Levine's 'Venereal Diseases, Prostitution and the Politics of Empire: The Case of British India' seeks to study the region of Awadh, her emphasis is also more on the Bengal and Madras Presidencies. ${ }^{4}$

1 See for example, Kokila Dang, 'Prostitutes, Patrons and the State: Nineteenth Century Awadh', Social Scientist, Vol. 21, Nos. 9-11, September-November, 1993, p. 173. See also Judith Walkowitz, Prostitution and Victorian Society: Women, Class and State, CUP, Cambridge, 1980, p. 2

2 K. Ballhatchet, Race, Sex and Class under the Raj: Imperial Attitude and Policies and their Crisis, 1793-1905, Villash Publishing House, New Delhi, 1979, pp. 10-11

3 Ibid.

4 Philippa Levine, 'Venereal Diseases, Prostitutions and the Politics of Empire: The Case of British India" Journal of the History of Sexuality, Vol. 4, No. A, 1994. 
Veena Oldenburg's study, The Making of Colonial Lucknow 1856-1877, pointed out how the social disease was deal with 1877, pointed out how the social disease was deal with chiefly as a medical problem by the British authorities.

To prevent the venereal diseases, the first lock hospitals in India were probably the four established in 1797 at Baharampur, Cawnpur (Kanpur), Danapur and Fatehgarh for 'the reception of diseased women'. ${ }^{5}$

The institution of the lock hospital was very oppressive is highlighted by a Lucknow Municipal Committee report of 1876 which pointed out that the '...the general regulation gives an opening for tyranny and oppression to the lock hospital.'6

The oldest lock hospital of Awadh and North Western Provinces was at Cawnpore. There was no change has been made in the hospital accommodation during the year 1878. Surgeon show officiating during the months of April, May and June and Surgeon Major J. B. Hamilton has been in medical charge since 18 $8^{\text {th }}$ December 1875. During the year 1878, 49 cases of Primary Syphilis and 117 cases of Gonorrhea were admitted from Ist battalion, $3^{\text {rd }}$ (The Buffs) Regiment and 4 cases of Syphilis Primary and 5 cases of gonorrhoea from F-5 (late F-19), Royal Artillery. On this number 10 cases of Syphilis and 21 cases of gonorrhoea among the Buffs were contracted out of the station and 6 refer to gonorrhoea. ${ }^{7}$

There were also some cases of venereal diseases were reported that contracted by the men of the same regiment from unregistered prostitutes which were 17 cases of syphilis and 32 cases of gonorrhoea. ${ }^{8}$ From F-5 Royal Artillery, 3 cases of syphilis and 4 cases of gonorrhoea were contracted out of the station, and no cases of syphilis and cases of venereal diseases were contracted from unregistered women. ${ }^{9}$

Increase and decrease of venereal cases among the women in the year 1877, 259 cases of syphilis which decreases in next year i.e., 1878 which decreased by 29. In the case of gonorrhoea, there was an increase of 74. In the year 1877-54 and in 1878- 130 cases found. The increase of gonorrhoea among women due to the vast majority of the cases was contracted by city prostitutes. ${ }^{10}$

5 Letter from the secretary to Military Board, dated 24 June 1799, Bengal Military Consultations, Ist to $30^{\text {th }}$ July, 1799 OIOC, P/19/57; Erica Wald, 'From Begums and Bibis to abandoned females and idle women: sexual relationships, venereal diseases and the redefinition of prostitution in early nineteenth-century India', Indian Economic Social History Review, 46,1,2009, p. 3

6 Home Department, Sanitary, August 1876, No. 414-15

7 Annual Report of Working of the Lock Hospitals, North Western Provinces and Oudh, N.W.P and Oudh Government Press, Allahabad, 1879, p. 1

8 Ibid.

9 Ibid.

10 Ibid., p. 2 
The increase and decrease of venereal cases also depend upon the sincerity of police. If the police do their duty properly venereal cases can be kept down in Cawnpore but if the police neglect the work and allow unlicensed prostitution, diseases would rapidly increase and assume alarming proportion. ${ }^{11}$

J. B. Hamilton, surgeon Major in charge of lock hospital mentioned that in year 1877 in annual report of lock hospital that the venereal cases in Cawnpore and the chief factor which he found in city that during the year 1876 the city was closed to the European troops on account of Cholera, and in December venereal diseases had fallen to 12 cases among the troops. The most important factor in all extent of venereal among Europeans for the past few years that has been quite a lost sight of viz. the army being now composed of much younger men, with a smaller proportion of married men, and very few old soldiers. ${ }^{12}$

The report of Lucknow lock hospital for the year 1878 submitted by Dr Fairland in charge on the working of the hospital for 1877, which mentioned that the extent of venereal diseases among the European troops decreased in admission and the percentages being only 15.2 against 25.7 of the year 1876. The total cases of primary syphilis were 58 in 1877 and 104 in $1876 .{ }^{13}$

The office memo of J. A.S. Hutchinson deputy Surgeon General, Lucknow dated $27^{\text {th }}$ February 1878 mentioned that the diseases were in a large proportion of Jats and Pathans regiments. On $27^{\text {th }}$ November 1877, he inspected the hospital of the regiment and found 14 cases of venereal diseases distributed as ${ }^{14}$ :

\begin{tabular}{|l|l|}
\hline Brahmin and Rajput Company & 01 \\
\hline H. Mussalmans & 01 \\
\hline Sikhs & 02 \\
\hline Dogras & 01 \\
\hline Pathans and Punjabi M. & 06 \\
\hline Ahirs & 00 \\
\hline Jats & 03 \\
\hline
\end{tabular}

Source: Annual Reports on working of Lock Hospital Northern Western Province and Oudh. 1878. P.83.

11 Ibid., p. 2

12 Ibid., p. 3

13 Annual Reports on working of Lock Hospital Northern Western Province and Oudh. 1878. P.79; No.92D, dated Lucknow, the 26 $6^{\text {th }}$ March, 1878. From Colonel James Reid, commissioner, Lucknow, division to Sanitary Commissioner, North Western Provinces.

14 Annual Reports on working of Lock Hospital Northern Western Province and Oudh. 1878. P.83 


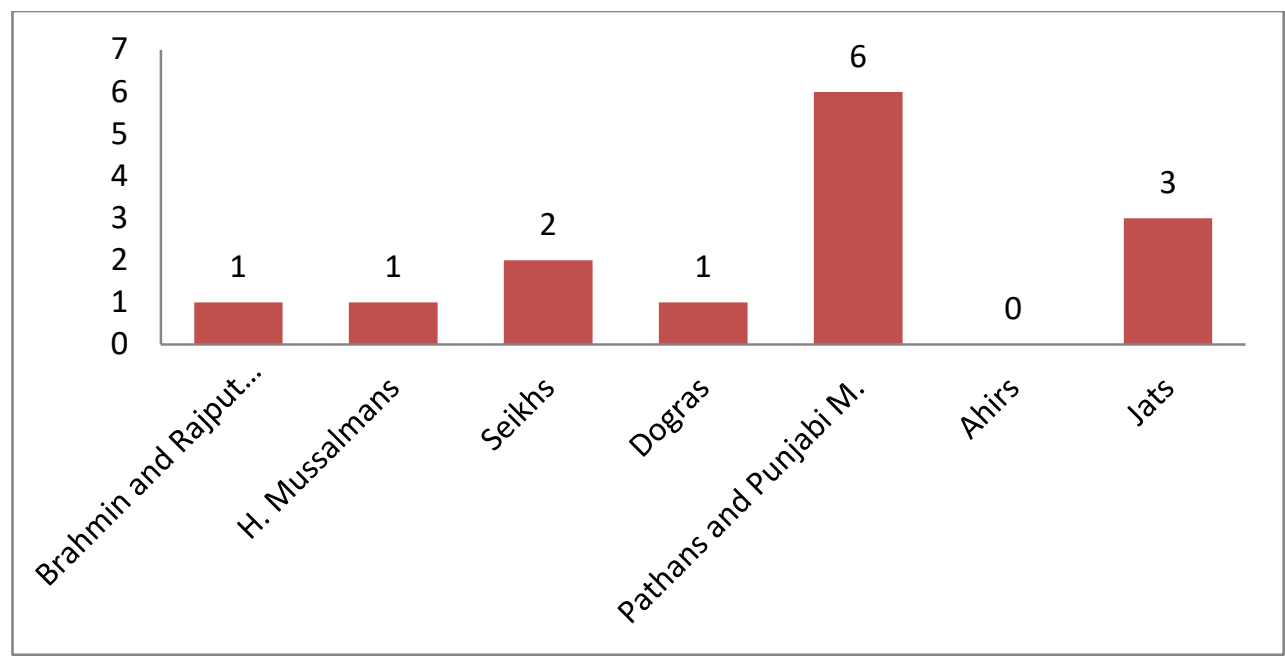

Source: Annual Reports on working of Lock Hospital Northern Western Province and Oudh. 1878. P.83

The cantonment Magistrate M. Horsford, Major mentioned that there were three different classes of unregistered women through which the diseases were contracted. First, native women who hang about the barracks, second European and half-caste prostitutes who lived in the city just outside the cantonments borders, and the third one was the native prostitutes who go with Europeans and lived in the streets and quarters bordering on cantonments. ${ }^{15}$

The annual reports on lock hospital at luck now cantonment for the year 1877 mentioned that the patients suffering from venereal cases are supplied with a cot and a blanket but wears her own clothing but sometimes the old hospitals clothing were received from the commissariat department for their use. ${ }^{16}$

The extent of venereal diseases among the Europeans troops from 1872-76 shown in the table ${ }^{17}$ :

\begin{tabular}{|c|c|}
\hline Year & $\begin{array}{c}\text { Percentage of venereal diseases among } \\
\text { the Europeans troops }\end{array}$ \\
\hline 1872 & 18.9 \\
\hline 1873 & 15.2 \\
\hline 1874 & 25.5 \\
\hline 1875 & 24.2 \\
\hline 1876 & 25.7 \\
\hline
\end{tabular}

Source: Annual Reports on working of Lock Hospital Northern Western Province and Oudh. 1878.

15 Ibid, p.84. The cantonment Magistrate M. Horsford, Major mentioned under memo on lock hospital reports for 1877 on dated $16^{\text {th }}$ March 1878

16 Ibid, p.85

17 Ibid. 
Jhss, Vol. 10, No. 1 , January to June, 2019



Source: Annual Reports on working of Lock hospital Northern Western Province and Oudh. 1878.

As far as the examination and treatment of the women concern they were very regular in their attendance at the bi-weekly inspections, only 22 women reported to the cantonment magistrate during the whole year for absence without leave. ${ }^{18}$ The speculum was used in every case. The examination room was suitable in all respects, the women were treated with tenderness and having no objection to the inspections. ${ }^{19}$

Monthly Admissions amongst the troops

\begin{tabular}{|c|c|c|}
\hline Months & Average Strength & No. of Admission \\
\hline January & 2361 & 29 \\
\hline February & 2398 & 31 \\
\hline March & 2498 & 35 \\
\hline April & 2455 & 35 \\
\hline May & 2398 & 24 \\
\hline June & 2351 & 40 \\
\hline July & 2342 & 23 \\
\hline August & 2339 & 26 \\
\hline September & 2289 & 21 \\
\hline October & 2255 & 32 \\
\hline November & 2194 & 30 \\
\hline December & 1644 & 20 \\
\hline
\end{tabular}

Source: Fourth Annual Reports on the Working of the Lock Hospitals in the NorthWestern Provinces and Oudh, 1877, p. 87.

$18 \quad$ Ibid., p. 86

19 Ibid. 


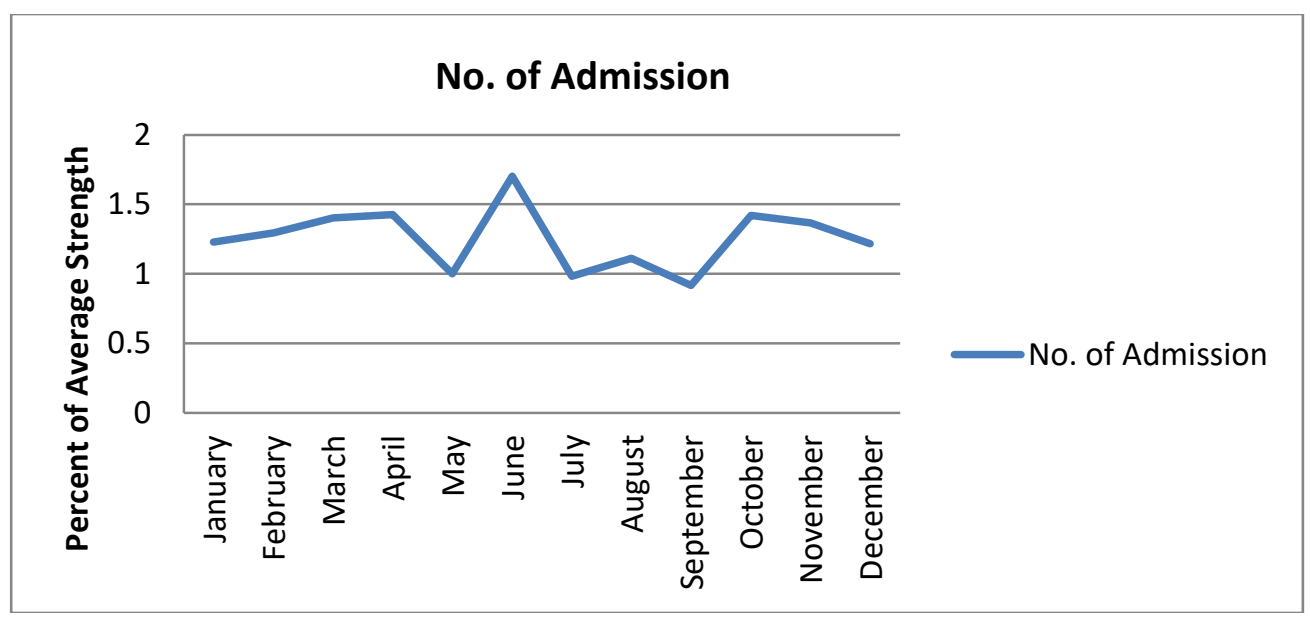

Source: Fourth Annual Reports on the Working of the Lock Hospitals in the NorthWestern Provinces and Oudh, 1877, p. 87.

Venereal Diseases amongst the troops in Lucknow from 1873-1877

\begin{tabular}{|c|c|c|c|c|}
\hline \multirow{2}{*}{ Year } & $\begin{array}{c}\text { Average } \\
\text { Strength }\end{array}$ & \multicolumn{3}{|c|}{$\begin{array}{c}\text { Admission to hospital for 1000 of the } \\
\text { average strength in each year }\end{array}$} \\
\cline { 3 - 5 } & & Pr. Syphilis & Gonorrhoea & Total Diseases \\
\hline 1873 & 2467 & 66 & 63 & 129 \\
\hline 1874 & 7525 & 92 & 142 & 234 \\
\hline 1875 & 2490 & 177 & 134 & 311 \\
\hline 1876 & 2332 & 104 & 152 & 255 \\
\hline 1877 & 2327 & 58 & 102 & 160 \\
\hline Total Average & $\mathbf{1 9 1 4 1}$ & $\mathbf{9 9}$ & $\mathbf{1 1 8}$ & $\mathbf{2 1 5}$ \\
\hline Average & $\mathbf{3 4 2 8 . 2}$ & & & \\
\hline
\end{tabular}


Jhss, Vol. 10, No. 1 , January to June, 2019

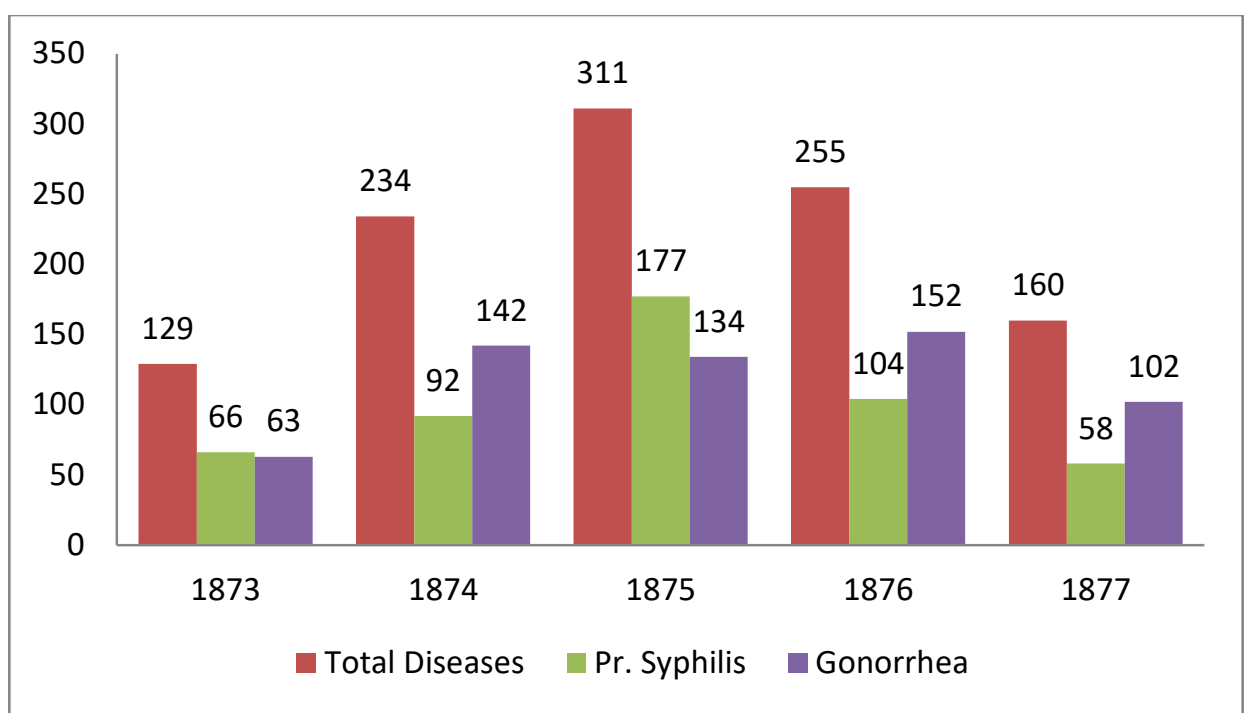

Source: Fourth Annual Reports on the Working of the Lock Hospitals in the NorthWestern Provinces and Oudh, 1877, p. 88.

Apart from all cases among Europeans troops there were venereal diseases also prevail in native regiments at Lucknow. The $4^{\text {th }}$ Regiment Native Infantry had 12 admissions in which 10 contracted in cantonments and one from Fort Machi Bhavan and the contracted at man's own home. ${ }^{20}$ The $6^{\text {th }}$ Bengal Light Infantry had 94 cases. The medical officer said that these all cases contracted at Aminabad. ${ }^{21}$

The Annual Statement No. II of the lock hospital at Lucknow cantonment for the year 1877 shows that a number of prostitutes found the disease at the periodical examination and treated in hospital from January to December 1877 was 412 which also included 34 unregistered prostitutes. As far as the diseases were a concern the total cases were 58 in which 12 cases of primary syphilis and 46 cases of gonorrhoea. ${ }^{22}$

The Fifth Annual Reports on the working of lock hospital at Lucknow for 1878 mentioned about the management was unsatisfactory. The ratio of admissions to hospital for venereal diseases amongst the European Garrison during the past five years has been 298, 389, 327, 206 and 292 per thousand respectively. ${ }^{23}$ The

20 Fourth Annual Reports on the Working of the Lock Hospitals in the North Western Provinces and Oudh, 1877, p. 91

21 Ibid.

22 Ibid., p. 93. For other details, see Table of Annual Reports Statements No. II of Lock Hospital at Lucknow cantonment for the year 1877

23 Fifth Annual Reports of Working of the lock hospital in the Northern Western Provinces and Oudh for the year 1878, Allahabad, 1879, p. 2. For details see the reports, table no. iv. 
admissions of European soldiers were greatest during the months of February and September. At the end of January, the 73rd regiment arrived in Lucknow and they brought 49 cases with them contracted on the month of March and 69 admitted to hospital in February. In September the 85th Regiment had 50 cases. In August to September 23 badly diseases unregistered women were admitted to the lock hospital. In view of the medical officer, these diseased women caused the disease among the soldiers. Further, he opinioned that the cause of the increase in number due to the famine. The police brought women were found deceased. They are described as young girls, or women with babes at the breast, not of the usual prostitute class, but women are driven to prostitution, through dread of actual starvation. ${ }^{24}$

The Sixth Annual Reports for the year 1879, during this year the ratio of admission to hospital for venereal disease amongst the European garrison has been 171 per 1000 of strength. ${ }^{25}$ The ratio of women was 596.6 and 156.1 amongst the soldiers for thousands for venereal diseases. ${ }^{26}$ The reports show that the venereal diseases amongst European soldiers of 1879 that the daily average strength of European garrison at Lucknow was 2081 and admission to hospital for venereal diseases were 356 in which 221 cases of gonorrhoea and 135 cases of syphilis. ${ }^{27}$

Seventh Annual Report of Lucknow Lock Hospital for the year 1880 shows that 8 cases of syphilis and 71 cases of gonorrhoea were detected amongst the women. However, among the troops, 414 cases of the venereal disease occurred in which 237 cases of syphilis and 177 cases of gonorrhoea. The ratio of disease to strength is a little in excess of that for the previous year. ${ }^{28}$

During 1881, 79 cases of contagious diseases were admitted to hospital. ${ }^{29}$ The ratio of admission to hospital for venereal disease amongst the soldiers was 259.0 per 1000.30 The registered women prevailing disease was gonorrhoea and soldiers prevailing disease was syphilis. However, the cause of increasing these diseases among the soldiers was due to their reckless conduct in cantonment life following upon the hardships of the Afghanistan campaign and a large portion of the garrison had returned will provide with money in term of batta and deferred pay. ${ }^{31}$ The ratio of disease varied greatly in different corps. The men of a battery resident three

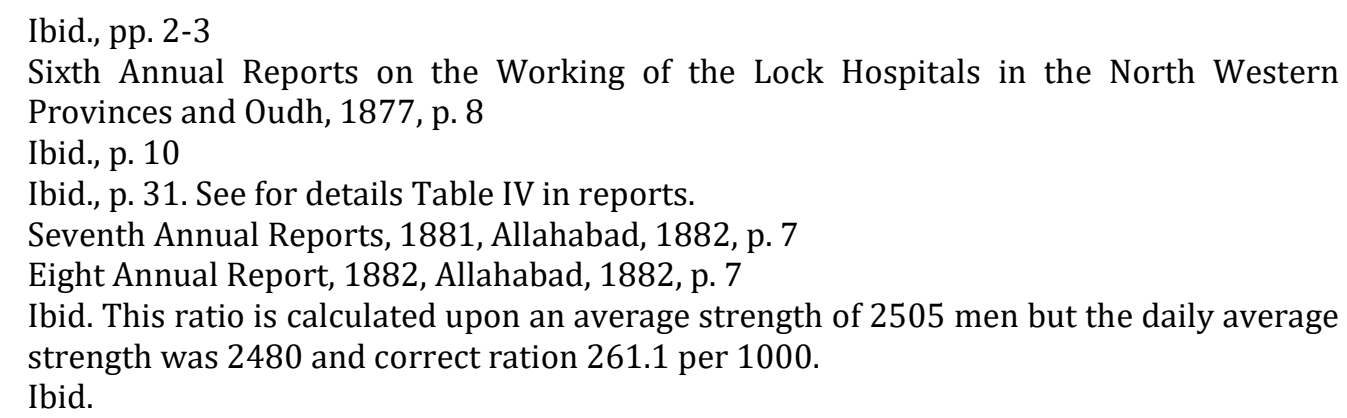


years at Lucknow had only 50 cases per 1000 . However, the men of a battery newly arrived from Afghanistan had 578 cases per $1000 .{ }^{32}$

As compared to 1881, the number of registered women was greater in 1882 . The main cause of the increase was the 12 women with Faizabad regiment returned with the regiment and the number of registered women does not meet the requirement. The result of the management was very unsatisfactory and the ratio of admission to hospital for venereal diseases amongst the European garrison was 348 per thousand. ${ }^{33}$ The daily average strength of European garrison in 1882 at Lucknow was 2716 in which 353 cases of gonorrhoea and 419 cases syphilis admitted in the hospital. ${ }^{34}$

The tenth annual reports of Lucknow lock hospital of the year 1883 mention that the management of the hospital was very satisfactory. The ratio of admissions to hospital for venereal diseases amongst the European soldiers has been 187 per 1000 of daily average strength. ${ }^{35}$

After Lucknow, another region of Oudh provinces has to be studied is Faizabad and Sitapur.

The ratio of admission to hospital for venereal diseases among the European garrison per thousands of daily average strength at Lucknow, Faizabad and Sitapur from 1874-83

\begin{tabular}{|c|c|c|c|}
\hline Year & Lucknow & Faizabad & Sitapur \\
\hline 1874 & 298 & 333 & - \\
\hline 1875 & 389 & 503 & 274 \\
\hline 1876 & 321 & 345 & 299 \\
\hline 1877 & 206 & 211 & 249 \\
\hline 1878 & 292 & 196 & 333 \\
\hline 1879 & 171 & 158 & 221 \\
\hline 1880 & 191 & 143 & - \\
\hline 1881 & 261 & 194 & 408 \\
\hline 1882 & 348 & 188 & 150 \\
\hline 1883 & 187 & 348 & 210 \\
\hline
\end{tabular}

Ibid.

Ninth Annual Report on working of Lock Hospital, 1882, Allahabad, p. 9

Ibid., p. 35

Tenth Annual Reports on Working of Lock Hospital, 1883, Allahabad, 1884, p. 8 


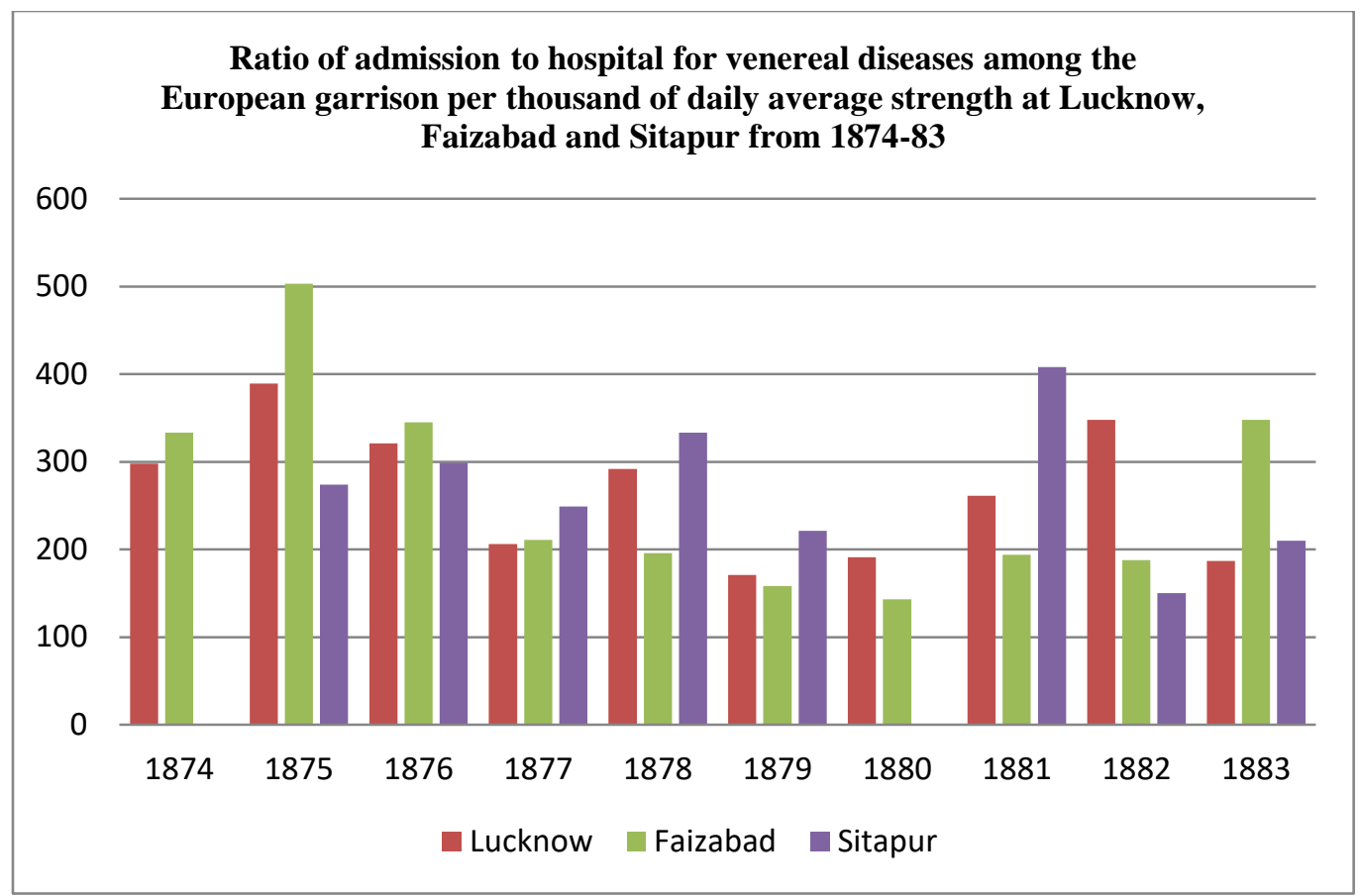

Source: Tenth Annual Reports on Working of Lock Hospital, 1883, Allahabad, 1884 The women's quitting hospital without permission under containment act 1899 pointed out by local officials and cantonment official used legal method to control. ${ }^{36}$

In 1900 from Bareilly in Oudh demonstrated that women could possibly dwell in the Sudder Bazar in the event that they consented to introduce themselves for examination deliberate once per week under changed CD act. In 1910, James Stuart requested that the Indian office reacts to claims that altered routine with regards to $\mathrm{CD}$ act still wins in India. The existed arrangement of examination of all Prostitution which can't be viewed as extremely intentional by any stretch of the imagination. ${ }^{37}$ We found some resistance from the women working in prostitution from the registration. One group of women in Agra successfully dithered registration for a day or two by wearing European clothes. ${ }^{38}$ Petitions from people and gathering ladies whining that they had been wrongly enlisted were typical. Be that as it may,

36 Major F.G. Cardew, department Secretary, Government of India, Military Department to Principal Medical Officer, H.M. Forces in India, 20 August 1901. OIOC, L/MIL/7/13920.

Cf. Philippa Levine, Prostitution, Race and Politics: Policing Venereal Disease in the British Empire, Routledge, New York, 2003, p.128.

37 Cf. Philippa Levine, Prostitution, Race and Politics: Policing Venereal Disease in the British Empire, Routledge, New York, 2003, p.128

38 Ibid, P.220 
Nautch women specifically, contended that the framework misjudged their place in the public eye and that they ought not to be required to enrol. ${ }^{39}$

In Lucknow, the tawaifs who had once danced for the Nawab of Oudh the privilege to stay outside the new system of registration. ${ }^{40}$ The current proof demonstrates that sorted out and formal challenges were increasingly basic among women working in British India.

\section{Conclusion:}

The specialized hospitals in India started in the mid-nineteenth century. Escalating fears of the terrible and radicalized results of venereal disease cleared to cross British India especially case considered zone Oudh. The more noteworthy vulnerability of British troops to sickness more than to battle made military metaphors intense. The interweaving of race and sex so substantial in this affiliations is depressingly reminiscent of the nineteenth century banters around pioneer sexuality and its connection to VD.

39 Ibid.

40 Ibid 


\section{References}

Annual Report of Working of the Lock Hospitals, North Western Provinces and Oudh, N.W.P and Oudh Government Press, Allahabad, 1879

Annual Reports on working of Lock Hospital Northern Western Province and Oudh. 1878. P.79; No.92D, dated Lucknow, the 26th March, 1878. From Colonel James Reid, commissioner, Lucknow, division to Sanitary Commissioner, North Western Provinces.

Cf. Philippa Levine, Prostitution, Race and Politics: Policing Venereal Disease in the British Empire, Routledge, New York, 2003

Eight Annual Report, 1882, Allahabad, 1882

Erica Wald, 'From Begums and Bibis to abandoned females and idle women: sexual relationships, venereal diseases and the redefinition of prostitution in early nineteenth-century India', Indian Economic Social History Review, 46,1,2009

Fifth Annual Reports of Working of the lock hospital in the Northern Western Provinces and Oudh for the year 1878, Allahabad, 1879

Fourth Annual Reports on the Working of the Lock Hospitals in the North Western Provinces and Oudh, 1877

Home Department, Sanitary, August 1876, No. 414-15

Judith Walkowitz, Prostitution and Victorian Society: Women, Class and State, CUP, Cambridge, 1980

K. Ballhatchet, Race, Sex and Class under the Raj: Imperial Attitude and Policies and their Crisis, 1793-1905, Villash Publishing House, New Delhi, 1979

Kokila Dang, 'Prostitutes, Patrons and the State: Nineteenth Century Awadh', Social Scientist, Vol. 21, Nos. 9-11, September-November, 1993

Letter from the secretary to Military Board, dated 24 June 1799, Bengal Military Consultations, Ist $^{\text {to }} 30^{\text {th }}$ July, 1799 OIOC

Major F.G. Cardew, department Secretary, Government of India, Military Department to Principal Medical Officer, H.M. Forces in India, 20 August 1901. OIOC, L/MIL/7/13920. Cf. Philippa Levine, Prostitution, Race and Politics: Policing Venereal Disease in the British Empire, Routledge, New York, 2003, p.128 
Jhss, Vol. 10, No. 1 , January to June, 2019

Ninth Annual Report on working of Lock Hospital, 1882, Allahabad

Philippa Levine, 'Venereal Diseases, Prostitutions and the Politics of Empire: The Case of British India" Journal of the History of Sexuality, Vol. 4, No. A, 1994

Seventh Annual Reports, 1881, Allahabad, 1882

Sixth Annual Reports on the Working of the Lock Hospitals in the North Western Provinces and Oudh, 1877

Table of Annual Reports Statements No. II of Lock Hospital at Lucknow cantonment for the year 1877

Tenth Annual Reports on Working of Lock Hospital, 1883, Allahabad, 1884 